\title{
Screening of Most Effective Nano Metal between AgNP, CuNP and Ag-Cu NP's Synergistic by In vitro Antibacterial Comparison
}

Patil PA*, Bhutkar BR, Dange YD and Kharat SV

Department of Pharmaceutical Chemistry, Rajarambapu College of Pharmacy Kasegaon, India

\begin{abstract}
The metal nanoparticles like silver, copper have attracted much attention as potential antimicrobial agents. In order to trace out very effective antimicrobial therapy needs in vitro comparison of these nanoparticles and Synergistic activity by combining these two molecules together for their commercial application. The present work concluded that CuNP are most potent antimicrobial agents in comparison to AgNP and synergistic activity.
\end{abstract}

Keywords: Antibacterial properties; Copper nanoparticles; Silver nanoparticles; Synergistic antimicrobial

\section{Introduction}

The silver and copper nanoparticles are emerged as novel antimicrobial therapy to solve the problems like microbial resistance and has shown promising commercial applications [1]. For commercial application of these nanomaterial's it is essential to sort out most potent antimicrobial agent between them. For this in vitro comparison of antimicrobial activity and also synergistic antimicrobial activity plays key role. While formulating commercial preparations it is necessary to use most potent antimicrobial agent in order to get ideal results. The in vitro evaluation was carried out by maintaining constant evaluation parameters like bioburdan, temperature, cup diameter, volume of testing sample in cup for proper evaluation.

\section{Material and Methods}

\section{Synthesis of NPs}

Silver nitrate an equal mole amount of salt was used concentration as $0.02 \mathrm{M}$, the reducing agent $0.5 \%$ and $1.5 \%$ trisodium citrate was added drop by drop during boiling the solution, the capping and stabilizing agent PVP was added in the concentration as $1 \%$ to the solutions. Colour change was prominent with change from colorless to pale yellow [1].

The salt used was copper sulfate pentahydrate $\left(\mathrm{CuSO}_{4} \cdot \mathrm{O}_{2}\right)$ A solution consisting of deionized water and the corresponding metal salt with concentration $0.1 \mathrm{M}$ and $0.2 \mathrm{M}$ was prepared with various concentrations of reducing agents $0.1 \mathrm{M}$ concentration of reducing agents $\left(\mathrm{NaBH}_{4}\right)$ was added . Excess concentration $1 \%$ of ascorbic acid. After the addition of the reducing agent the solution was stirred and kept at room temperature (Table 1). Finally, to store the nanoparticles and avoid unstability PVP was added in a sufficient amount to submerge them completely $[2,3]$.

\section{Characterization}

The synthesized $\mathrm{Cu}, \mathrm{Ag}$ and bimetallic $\mathrm{Cu}-\mathrm{Ag}$ NPs were characterized, UV-visible spectrophotometry at $420 \mathrm{~nm}$. The particle size of corresponding nanoparticles was determined on Malvern particle size analyzer instrument NS 300 model $[4,5]$.

\section{Antibacterial Activity}

The antimicrobial evaluation was done by keeping all parameters constant bioburdan, temperature, cup diameter, volume of testing sample in cup for proper evaluation. The experiments on the antimicrobial activity were carried out. The parameters were kept constant by using four petri dishes as follow:

\section{Temperature}

The nanoparticles were poured in the four petridishes consisting of different concentrations and then this petridishes temperature were kept constant by placing it in the incubator which had the same and uniform temperature $\left(37^{\circ} \mathrm{C}\right)$ throughout the growth of the organisms as well as for the antimicrobial activity evaluation study [6,7].

\section{Bio burden}

E.Coli was used in the this evaluation by using the same strain in all the petri dishes and at the same time it was incubated for 24 hours so as to keep the uniformity in the growth environment and growth rate [8].

\section{Diameter of the cup}

The cup plate method was used in the study and the cups diameter was kept constant by using the cork borer, each petri dishe had two cups consisting of the silver and copper nanoparticle for the evaluation of the synergistic activity of the nanoparticles.

\section{Volume}

The volume of the $\mathrm{NP}_{\mathrm{s}}$ was constant for synergistic activity it was half the quantity of both $\mathrm{NP}_{\mathrm{s}}$. For others the cups were filled to the maximum volume by using the syringe.

Antimicrobial activity of the synthesized $\mathrm{NP}_{\mathrm{s}}$ was tested against the human pathogenic bacteria Escherichia coli by determining the minimal inhibitory concentration (MIC) and minimal bactericidal concentration (MBC) following the cup-plate method. Selective media were used to culture each strain. For culturing E. coli the agars used were: The samples were initially incubated at $37^{\circ} \mathrm{C}$ for $24 \mathrm{~h}$ for the bacterial culture. Each set was inoculated aseptically with $10 \mathrm{~mL}$ of the respective bacterial suspension (approximately $10^{8} \mathrm{CFU} / \mathrm{mL}$ ) [9]. We used a positive control (only bacteria) and a negative control (only

*Corresponding authors: Patil PA, Department of Pharmaceutical Chemistry, Rajarambapu College of Pharmacy, Kasegaon, India, Tel: +91 9657651667; E-mail: prithvirajpatil87@gmail.com

Received January 06, 2016; Accepted February 08, 2016; Published February 16, 2016

Citation: Patil PA, Bhutkar BR, Dange YD, Kharat SV (2016) Screening of Most Effective Nano Metal between AgNP, CuNP and Ag-Cu NP's Synergistic by In vitro Antibacterial Comparison. J Nanomed Nanotechnol 7: 353. doi:10.4172/21577439.1000353

Copyright: ( 2016 Patil PA, et al. This is an open-access article distributed under the terms of the Creative Commons Attribution License, which permits unrestricted use, distribution, and reproduction in any medium, provided the original author and source are credited. 
Citation: Patil PA, Bhutkar BR, Dange YD, Kharat SV (2016) Screening of most Effective Nano Metal between AgNP, CuNP and Ag-Cu NP's Synergistic by In vitro Antibacterial Comparison. J Nanomed Nanotechnol 7: 353. doi:10.4172/2157-7439.1000353

Page 2 of 3

\begin{tabular}{|c|c|c|c|c|c|c|}
\hline Sr.no. & Nano Particle & Concentration (M) & Concentration of Reducing Agent & Capping Agent (1\%) & $\begin{array}{l}\text { Particle size (nm) } \\
\text { Average }\end{array}$ & $\begin{array}{l}\text { U.V. Absorbance } \\
(400 \mathrm{~nm})\end{array}$ \\
\hline 1. & Silver nanoparticle & 0.02 & $5 \mathrm{ml} 0.5 \%$ trisodium citrate & - & $40-60 \mathrm{~nm}$ & 0.371 \\
\hline 2. & Silver nanoparticle & 0.02 & $6 \mathrm{ml} 1.5 \%$ trisodium citrate & - & $40-60 \mathrm{~nm}$ & 0.270 \\
\hline 3. & Silver nanoparticle & 0.02 & $4 \mathrm{ml} 0.5 \%$ trisodium citrate & PVP & $40-60 \mathrm{~nm}$ & 0.148 \\
\hline 4. & Silver nanoparticle & 0.02 & $5 \mathrm{ml} 1.5 \%$ trisodium citrate & PVP & $40-60 \mathrm{~nm}$ & 0.202 \\
\hline 5. & Copper nanoparticle & 0.1 & $4 \mathrm{ml} 0.1(\mathrm{M})$ sodium borohydride & - & $40-60 \mathrm{~nm}$ & 0.242 \\
\hline 6. & Copper nanoparticle & 0.1 & $7 \mathrm{ml} 0.1(\mathrm{M})$ sodium borohydride & & $40-60 \mathrm{~nm}$ & 0.091 \\
\hline 7. & Copper nanoparticle & 0.2 & $2 \mathrm{ml} 0.1(\mathrm{M})$ sodium borohydride & PVP & $40-60 \mathrm{~nm}$ & 0.08 \\
\hline 8. & Copper nanoparticle & 0.2 & $10 \mathrm{ml} 0.1(\mathrm{M})$ sodium borohydride & PVP & $40-60 \mathrm{~nm}$ & 0.170 \\
\hline
\end{tabular}

Table 1: Synthesis of nanoparticles.

$\mathrm{NP}_{\mathrm{s}}$ ). Tests were performed three times for each strain. The inoculated sets were incubated at $37^{\circ} \mathrm{C}$ for $24 \mathrm{~h}$. The zone of inhibition in each plate were observed and calculated, also in the present study we also invented novel technology of angle of inhibition for antimicrobial activity calculation was by using protractor III camera software for better evaluation of antibacterial activity [1].

\section{Synergistic Antibacterial Activity}

To analyze synergistic antibacterial activity of CuNP and AgNP, they were mixed at equal volume, no spontaneous reaction, no separation of phases was observed after mixing.

\section{Results}

Inhibition is shown in the (Figure 1) and the graph of antibacterial activity is shown in Figure 2.

In the Figure 2: A, B, C and D are denoted as follows

A- $0.5 \%$ trisodium citrate $0.02 \mathrm{M} \mathrm{AgNO}_{3}+0.1 \mathrm{M} \mathrm{CuSO}_{4}+$ Combine effect

B- $1.5 \%$ trisodium citrate $0.02 \mathrm{M} \mathrm{AgNO}_{3}+0.2 \mathrm{MCuSO}_{4}+$ combine effect

C- $0.5 \%$ trisodium citrate $0.02 \mathrm{M} \mathrm{AgNO}_{3}+0.1 \mathrm{M} \mathrm{CuSO}_{4}+$ Combine effect with capping agent

D- $1.5 \%$ trisodium citrate, $0.02 \mathrm{M} \mathrm{AgNO}_{3}+0.2 \mathrm{M} \mathrm{CuSO}_{4}+$ combine effect with capping agent

Table 2 shows the concentration and angle inhibition.

I- $0.02 \mathrm{M} \mathrm{AgNO}_{3} 0.5 \%$ trisodium citrate

II- $0.02 \mathrm{M} \mathrm{AgNO}_{3}$ 1.5\% trisodium citrate

III- $0.02 \mathrm{M} \mathrm{AgNO}_{3}$ 0.5\% trisodium citrate $1 \%$ (PVP)

IV- $0.02 \mathrm{M} \mathrm{AgNO}_{3} 1.5 \%$ trisodium citrate $1 \%$ (PVP)

I- $0.1 \mathrm{M} \mathrm{CuSO}_{4} \mathrm{NaBH}_{4}$

II- $0.1 \mathrm{M} \mathrm{CuSO}_{4} \mathrm{NaBH}_{4}$ (PVP)

III- $0.2 \mathrm{M} \mathrm{CuSO}_{4} \mathrm{NaBH}_{4}$

IV- $0.2 \mathrm{M} \mathrm{CuSO}_{4} \mathrm{NaBH}_{4}(\mathrm{PVP})$

\section{Conclusions}

The copper nanoparticles are most effective antimicrobial agent than silver nanoparticles and copper-silver synergistic out of various concentrations of copper nanoparticles $0.1 \mathrm{M}$ copper nanoparticles coated with PVP shows maximum zone of inhibition and angle of inhibition. The synergistic effect of these two nanoparticles also increases antibacterial activity. The novel angle of inhibition by protractor III camera for evaluation antimicrobial activity is successfully invented (Figure 3).

\begin{tabular}{|c|c|c|c|c|c|c|c|c|c|c|c|c|c|}
\hline \multirow{2}{*}{\begin{tabular}{|l} 
Sr.no. \\
1. \\
\end{tabular}} & \multirow[b]{2}{*}{ Concentration } & \multicolumn{4}{|c|}{$\begin{array}{l}\text { Silver } \\
\text { nanoparticle }\end{array}$} & \multicolumn{4}{|c|}{$\begin{array}{l}\text { Copper } \\
\text { nanoparticle }\end{array}$} & \multicolumn{4}{|c|}{ Synergistic } \\
\hline & & 1 & II & III & IV & 1 & II & III & IV & A & B & C & $D$ \\
\hline 2. & $\begin{array}{l}\text { Zone of } \\
\text { Inhibition }(\mathrm{cm})\end{array}$ & 0.3 & 0.3 & 0.4 & 0.3 & 0.8 & 1 & 0.6 & 0.5 & 0.7 & 0.6 & 0.5 & 0.8 \\
\hline 3 & $\begin{array}{l}\text { Angle of } \\
\text { inhibition } \\
\text { (degree) }\end{array}$ & 2.9 & 2.9 & 4.7 & 2.9 & 18 & 20.8 & 16 & 15 & 17 & 16 & 15 & 18 \\
\hline
\end{tabular}

Table 2: Concentration, zone inhibition and angle inhibition of nanoparticles.

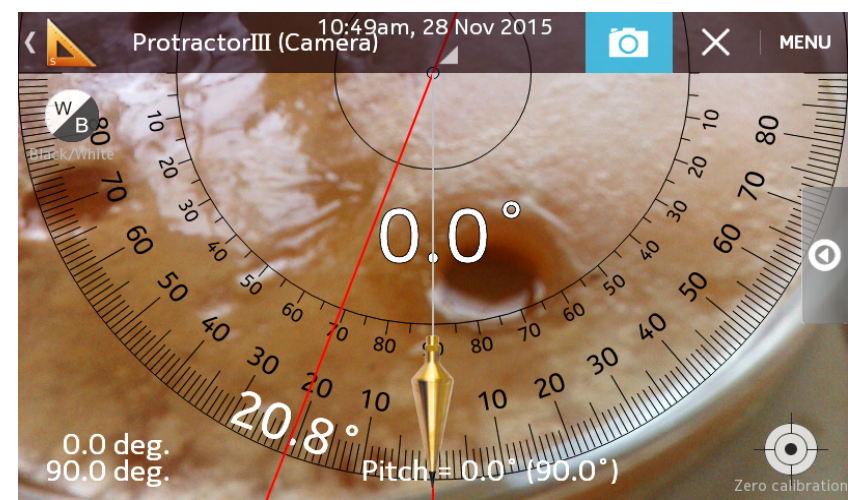

Figure 1: Shows maximum angle of inhibition $20.8^{\circ}$ and zone of inhibition $1 \mathrm{~cm}$ for $0.1 \mathrm{M}$ CuSO4 NaBH4 (PVP).

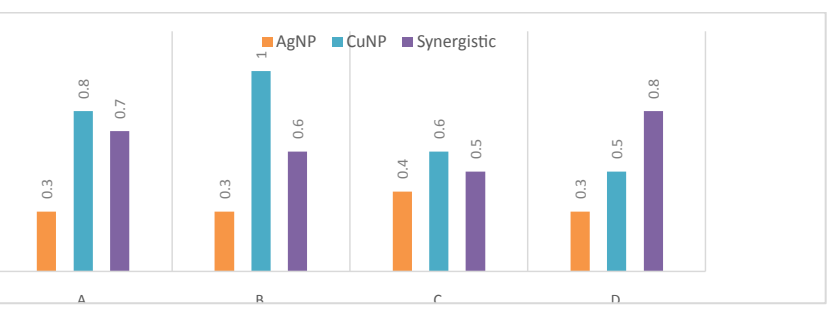

Figure 2: Graph shows antibacterial activity. 
Citation: Patil PA, Bhutkar BR, Dange YD, Kharat SV (2016) Screening of most Effective Nano Metal between AgNP, CuNP and Ag-Cu NP's Synergistic by In vitro Antibacterial Comparison. J Nanomed Nanotechnol 7: 353. doi:10.4172/2157-7439.1000353

Page 3 of 3

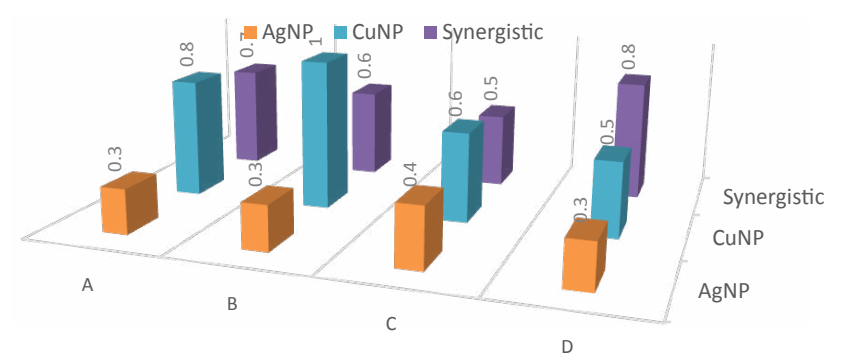

Figure 3: Antimicrobial activity comparison.

\section{References}

1. Dong PV, $\mathrm{Ha} \mathrm{CH}$, Binh LT, Kasbohm J (2012) Chemical synthesis and antibacterial activity of novel-shaped silver nanoparticles. International Nano Letters.

2. Lee Y, Choi J, Lee KJ, Stott NE, Kim D (2008) Large-scale synthesis of coppe nanoparticles by chemically controlled reduction for applications of inkjetprinted electronics IOP Publishing Ltd 19: 41.
3. Pacioni NL, Borsarelli CD, Rey V, Veglia AV (2015) Synthetic Routes for the Preparation of Silver Nanoparticles Silver Nanoparticle Applications Engineering Materials. Springer International Publishing Switzerland, USA.

4. Khan Z, Al-Thabaiti SA, Obaid AY, Al-Youbi AO (2011) Preparation and characterization of silver nanoparticles by chemical reduction method. Elsevier publication 82: 513-517.

5. Manivel P, Sivashanmugan K, Viswanathan C, Mangalaraj D (2011) Preparation of New Reducing Agent for the Synthesis of Silver Nanoparticles. American institute of physics.

6. El-Nour KMMA, Eftaiha A, Al-Warthan A , Ammar RAA (2010) Synthesis and applications of silver nanoparticles. Arabian Journal of Chemistry 3: 135-140.

7. Solomon SD, Bahadory C, Jeyarajasingam AV, Rutkowsky SA, Boritz C (2007) Synthesis and Study of Silver Nanoparticles. Journal of Chemical Education 84: 322

8. Zielinska A, Skwarek E, Zaleska A, Gazda M, Hupka J (2009) Preparation of silver nanoparticles with controlled particle size. Procedia Chemistry 1: 15601566.

9. Prabhu S, Poulose EK (2012) Silver nanoparticles: mechanism of antimicrobial action, synthesis, medical applications, and toxicity effects. International Nano Letters 2: 32. 